\title{
To Compose with Gaia: Living Sympoetically
}

\section{Sean Sturm ${ }^{1}$}

Published online: 22 June 2020

(C) Springer Nature Switzerland AG 2020

Keywords Covid-19 · Latour · Stengers · Gaia · Composition · Symbiosis · Philosophy of education

[W]e do not have any choice, because [Gaia] will not wait. (Stengers 2015: 50)

\section{Death or Symbiosis}

The moment that is 'the coronavirus' distends as slow disasters do. We 'non-essential workers' wait and weigh the space between us. As we do our best to fill our bubbles with meals, news updates, Zooms, walks, and worries, invisibilities coalesce in the corners of our eyes:

- A virus that leaps from bats to pangolins to people - from mouths to hands to faces

- A 'market' that delivers some their food and others their ventilators

- 'Essential workers' (who keep us non-essentials alive)

- 'Social distance' and 'self-isolation'

- 'The new normal.'

The 'new normal' we see is the Prime Minister addressing us daily from the TV, messages proclaiming 'This is a Covid-19 announcement...,' police crawling by, people queuing for supplies (though we have pinot and pesto, there is no toilet paper or flour). It is polite penury. But because the sun is out and we can get about, things do not seem too bad. We are dreaming the futureless now of the overdeveloped world.

Sean Sturm

s.sturm@auckland.ac.nz

1 Faculty of Education and Social Work, University of Auckland, Auckland, New Zealand 
But the arrival of the 'novel' coronavirus - novel only to humans, it must be said — tells us that Gaia will not wait (Stengers 2015). It tells us that, before the virus arrived, we already lived in 'pneumatic bubbles' (Sloterdijk 2011: 49); that we have unlearned how to live in the weather, with its lasting seasons and passing moods; that, as we have lived out some version of the ghostly passage of the $1 \%$ from air-conditioned home/hotel to car to office to car to restaurant/gym/plane to home/hotel, we have exhaled our waste and exhausted the world. Michel Serres prophesied the consequences of this ghastly excremental economy in The Natural Contract (1995). There he argued that, as a result of our drive to master and possess the world, which we attempt to mark as ours by defiling it, '[w]e have lost the world' (Serres 1995: 29). But all is not lost. The world is now 'reminding us of its existence' (29) by 'turning [our mastery] back on itself' (34). Gaia is 'intruding' on our dream of existence by blowing a deadly virus our way like a cannibal wind (Stengers 2015). And in the air is the hint that what we are waiting for - the return to the old normal-will never arrive.

What is to be done, then, we ask? First of all, as Serres (1995: 33) has said, we must cease to assume that nature centres on us; we must 'place things in the centre and us at the periphery, or better still, things all around and us within them like parasites.' For Serres, this move requires that we counter the Copernican revolution, in the original and Kant's sense. Counter-intuitively for us as would-be moderns, we must put the Earth — or Gaia — at the center of things, and we must again attend to existences other than humans (subjects) as more than mere things (objects). Or, to put it another way, we must counteract our parasitism with justice, by making all things - including humans (and our companion and prey species) - 'legal subjects' of a natural contract (Serres 1995: 37).

To do so would be to subsume the guiding concepts of modernity, namely, the 'social contract' and 'natural law' (by which laws, it is said, we emerge from a state of nature and reduce nature to human nature respectively), under a natural contract that bonds us - hosts and parasites — as fellow natural things, or 'symbionts' (Serres 1995: 34; see Haraway 1995). This natural contract binds us human beings with a stark choice: 'death or symbiosis' (Serres 1995: 34), as Gaia's judo move on us proves. It recalls us as symbionts to our responsibility to live sympoetically. It thus requires of us 'attention, reciprocity, contemplation, and respect' (Serres 1995: 38), or, in Haraway's (2016: 34) apt term, 'response-ability.'

\section{Symbiosis, or Living Sympoetically}

But what might living sympoetically mean in practice? For Stengers (2015: 50), it means 'composing with Gaia.' Composing with Gaia might be taken as a proxy for what Katharina Hoppe (2019: 13-14) calls 'composing with otherness,' or 'collectively rearranging relations, actors, and collectives' to actualize new ways of becoming. Our existence, like all existences, is based on a 'very specific, partial manner of relating with the world' (Stengers 2017: 393), of 'privileging and discarding' certain other existences (385), partial because it is limited in its capacities (or expressions) and specific in its interests (or values). So as not to be closed off to 'matters of critical concern' (396) beyond our existential purview — outside our bubble — we need to be open to composing with others, to 'the creation of always partial connections, 
producing new relevant possibilities' (Stengers 2014: 202), to our response-ability to other existences.

Firstly, then, composing - literally, 'placing' (-posing) 'together' (com-)—implies assemblage, namely, the convocation and commingling of heterogeneous things. But, for Stengers, how the assemblage comes about matters. It should not result from the kind of acts of petty despotism that accompany human individualism or exceptionalism, acts by which human beings position themselves at the head of Leviathan-like commonwealths. Elon Musk's plan to terraform Mars by 'nuking' it is such an act (Wall 2019), but there are countless other despotic acts of less obvious hubris undertaken by humans every day. For example, in the lockdown, I have taken a perverse solace in my fellow animals. I have enjoyed getting to know the daily rhythms of our two cats at home, as they come and go, sleep, nestle, and feed, but I also (uncharacteristically) chose to cook steak in lieu of going out to celebrate the end of 2 weeks in isolation - much to the disgust of our vegan children.

But though I am a hypocrite, I am not a fatalist. I did not assemble the celebratory meal as some sort of tribute to nature or back-to-nature rite (but neither did I feed the meat to the cats out of shame at my hypocrisy). So I agree with Stengers that an assemblage should not result from an act of propitiatory despair. We ate meat out of a peculiar nostalgia for a life made distant by the lockdown. I am also not a Pollyanna. As Stengers would say, an assemblage - like the one that comprises Covid-19, a lockdown, my wife and I, children, cats (companion animals), meat (prey animals), and veganism - does not necessarily bring about the kind of polite democracy that marks what Latour (2004: 53) calls the 'progressive composition of a common world' of things. Our children chided us, while we lorded it over the cats and cows; Covid-19 kept us at home and occasioned our lapse into carnivorism. The assemblage was a cosmopolitical one, not a cosmopolitan one (see Stengers 2005a). Nonetheless, 'our' celebration did call and gather together a new assemblage of heterogeneous existences.

Secondly, composing - which can also mean arranging artistically (as musicians or painters do) -implies activism (Massumi 2011), namely, creative experiments in what Stengers (2014: 199) calls 'common sense' (by which she means acts of collective sensing, rather than folk wisdom). As she puts it, such experiments are about 'taking an interest for the way others make their world matter, including animal others, for tales about different ways of life, for experimenting with what may be possible' (Stengers 2014: 200). I have certainly been 'wandering and wondering,' as she suggests we do. I run every second day, because going out for exercise is allowed under the lockdown rules. Running, for me, is more than a way of staying active; it is a way of experimenting with the world. It is, as Stengers (2014: 203) says of such experimentation, a 'jump' that connects where you are with that which demands a response. It is a leap from, not off, the ground; a leap for, not to, somewhere. So it is that running allows me, as a shy human, to pass through others' existences (or by them, under lockdown) and connect with them via a glance, a nod of the head or a wave. (I must confess that I am fond of saluting trees or birds or the dawn as I run-I have always felt shyer of people than of the world.) Running allows me to feel more at home in a place, whether that be on my usual routes or when I travel for research ... or to escape a lockdown. In the lockdown, it has the frisson that comes from sensing the surface tension of other people's bubbles, attuned as we are by fear of the virus to the oddly diffuse assemblage that is our existence as a people. 
But, finally, composing is not composing with just any otherness because Gaia is a certain kind of other, an other too big for us to contend with, one in the face of which we struggle to retain our composure. For Stengers, Gaia is not Mother Earth, Earth as our home planet or any other anthropomorphic entity, it is just 'the one who intrudes' (Stengers 2015: 43) on the big bubble that is the anthroposphere (Sloterdijk 2011), the one who 'signals a global threat' (Stengers 2017: 389). Such is its power that it appears to us in many guises, or, for us would-be moderns, threats: human overpopulation, environmental degradation, global warming, mass extinctions, hostile artificial intelligence, and global pandemics. But its power may finally strike home for us with the arrival of Covid-19, which seems to threaten our lives, livelihoods, and lifestyles, and thwart the dividing lines that we draw between humans, animals, and machines - each of which can be host, vector, or pathogen for the others.

For example, the official advice from our Ministry of Health on wearing masks is that to do so serves not to protect ourselves from infection, but to protect others from us, should we be asymptomatic carriers. (Nonetheless, I am most afraid of picking up the virus and infecting my family because I cannot help but be partial to those closest to me.) But, although we have been primed by modernism to see the virus as an 'existential threat' to our species or civilization (Anthony 2020), what its arrival really does is draw our attention to the problem that 'a major unknown, which is here to stay, exist[s] at the heart of our lives,' as Stengers (2015: 47) puts it. Gaia is not threatened; Gaia asks nothing of us; Gaia does not offer us a choice. Gaia simply recalls us as symbionts to our responsibility to live sympoetically.

Thus, to compose with an other such as Gaia involves a certain sort of attention, namely, the activation of assemblages that do three things (Tola 2016). ${ }^{1}$ First, activist assemblages do not deny that 'we are not alone in the world' (Stengers 2005a: 192). Our existence is co-existence, whether we like it or not. Second, activist assemblages enact 'a world where many worlds fit,' each a 'world in the making' (Stengers 2018: 83, 90). Existences do co-exist, though often uneasily. Third, activist assemblages affirm that there is magic in the world if we think 'for the world and not against it' (Stengers 2005b: 188). We can open ourselves to other existences. Perhaps Serres' (1995: 29) prophesy that '[w]e have lost the world' is premature. Perhaps the deadly virus that has blown our way will usher in not a 'new normal,' but a world in which the new is normal-like the one heralded by the prophecy of the coming of the Pākehā (white settlers) to Tāmaki Makaurau/Auckland:

He aha te hau e wawara mai? He tiu, he raki...2

(What is the wind that softly murmurs? It is the north wind, the wind from the north....)

Tāmaki Makaurau/Auckland, March-May 2020.

\footnotetext{
${ }^{1}$ I wrote this essay in part in response to Hans Schildermans' wonderful essay 'The University in the Anthropocene' (Schildermans 2019), which suggested to me the threefold concept of assemblage (ontology), activism (ethics), and attention (education).

${ }^{2}$ These are the first two lines of a prophesy uttered by a local Māori (New Zealand indigenous) prophet, Titahi, before the arrival of the Pākehā (white settlers) in Tāmaki Makaurau/Auckland in the eighteenth century.
} 


\section{References}

Anthony, A. (2020). What if Covid-19 isn't our biggest threat? The Guardian, 26 April. https://www. theguardian.com/science/2020/apr/26/what-if-covid-19-isnt-our-biggest-threat . Accessed 30 May 2020.

Haraway, D. (1995). Cyborgs and symbionts: Living together in the new world order. In C. H. Gray (Ed.), The cyborg handbook (pp. xi-xx). New York, NY: Routledge.

Haraway, D. (2016). Staying with the trouble: Making kin in the Chthulucene. Durham, NC: Duke University Press.

Hoppe, K. (2019). Responding as composing: Towards a post-anthropocentric, feminist ethics for the Anthropocene. Distinktion: Journal of Social Theory, 1-18. https://doi.org/10.1080/1600910 X.2019.1618360.

Latour, B. (2004). Politics of nature: How to bring the sciences into democracy. Trans. C. Porter. Cambridge, MA: Harvard University Press.

Massumi, B. (2011). Semblance and event: Activist philosophy and the occurrent arts. Cambridge, MA: MIT Press.

Schildermans, H. (2019). The university in the Anthropocene: Proposing a pedagogy of study practices that make thought creative of the future. In K. Stemhagen (Ed.), Philosophy of Education Yearbook 2019 (pp. 243-254). Urbana, IL: Philosophy of Education Society. https://educationjournal.web.illinois. edu/ojs/index.php/pes/article/view/315/201. Accessed 30 May 2020.

Serres, M. (1995). The natural contract. Trans. E. MacArthur and W. Paulson. Ann Arbor, MN: University of Michigan Press.

Sloterdijk, P. (2011). Spheres 1: Bubbles. Trans. W. Hoban. Los Angeles, CA: Semiotext(e).

Stengers, I. (2005a). The cosmopolitical proposal. In B. Latour \& P. Weibel (Eds.), Making things public: Atmospheres of democracy (pp. 994-1003). Cambridge, MA: MIT Press.

Stengers, I. (2005b). Introductory notes on an ecology of practices. Cultural Studies Review, 11(1), $183-196$. https://doi.org/10.5130/csr.v11i1.3459.

Stengers, I. (2014). Speculative philosophy and the art of dramatization. In R. Faber \& A. Goffey (Eds.), The allure of things: Process and object in contemporary philosophy (pp. 188-217). London: Bloomsbury. https://doi.org/10.5040/9781472594242.ch-010.

Stengers, I. (2015). In catastrophic times: Resisting the coming barbarism. Trans. A. Goffey. London: Open Humanities Press. http://openhumanitiespress.org/books/download/Stengers_2015_In-CatastrophicTimes.pdf. Accessed 30 May 2020.

Stengers, I. (2017). Autonomy and the intrusion of Gaia. South Atlantic Quarterly, 116(2), 381-400. https://doi.org/10.1215/00382876-3829467.

Stengers, I. (2018). The challenge of ontological politics. In M. de la Cadena \& M. Blaser (Eds.), A world of many worlds (pp. 83-111). Durham, NC: Duke University Press.

Tola, M. (2016). Composing with Gaia: Isabelle Stengers and the feminist politics of the Earth. PhaenEx, 11(1), 1-21. https://doi.org/10.22329/p.v11i1.4390.

Wall, M. (2019). Elon Musk floats 'nuke Mars' idea again (he has t-shirts). Space, 17 August. https://www. space.com/elon-musk-nuke-mars-terraforming.html. Accessed 30 May 2020. 